\title{
Detection of Latent Monilinia Infections in Nectarine Flowers and Fruit by qPCR
}

\author{
C. Garcia-Benitez, P. Melgarejo, and A. De Cal, Department of Plant Protection, Instituto Nacional de Investigación y Tecnología Agraria y \\ Alimentaria (INIA), 28040 Madrid, Spain
}

\begin{abstract}
Most stone fruit with a latent brown rot infection caused by Monilinia do not develop visible signs of disease until the arrival of fruit at the markets or the consumer's homes. The overnight freezing-incubation technique (ONFIT) is a well-established method for detecting latent brown rot infections, but it takes between 7 to 9 days. In this report, we inform on the advantages of applying a qPCR-based method to (i) detect a latent brown rot infection in the blossoms and fruit of nectarine trees (Prunus persica var. nucipersica) and (ii) distinguish between the Monilinia spp. in them. For applying this qPCR-based method, artificial latent

infections were established in nectarine flowers and fruit using $10 \mathrm{Mon}$ ilinia fructicola isolates, $8 \mathrm{M}$. fructigena isolates, and $10 \mathrm{M}$. laxa isolates. We detected greater amounts of $M$. fructicola DNA than M. laxa and $M$. fructigena DNA in latently infected flowers using qPCR. However, greater DNA amounts of M. laxa than $M$. fructicola were detected in the mesocarp of latently infected nectarines. We found that the qPCRbased method is more sensitive, reliable, and quicker than ONFIT for detecting a latent brown rot infection, and could be very useful in those countries where Monilinia spp. are classified as quarantine pathogens.
\end{abstract}

Monilinia spp. are fungal causal agents of fruit brown rot, which is an economically important fungal disease of nectarines (Prunus persica [L.] Batsch var. nucipersica [Suckow] C. K. Schneid), peaches ( $P$. persica), and other stone fruit species, and is responsible for substantial preharvest and postharvest losses (Byrde and Willetts 1977). Until 2006, two Monilinia spp., namely M. fructigena Honey and M. laxa (Aderh. \& Ruhland) Honey, were identified as the causal fungi of brown rot in peaches and nectarines in Spain (De Cal et al. 2009). In 2006, M. fructicola (G. Winter) Honey, a European and Mediterranean Plant Protection Organization (EPPO) A1 quarantine pest until 2004 and now classified as an EPPO A2 (EPPO 2009) quarantine pest, was identified for the first time in peach and nectarine orchards in northeastern Spain (De Cal et al. 2009). Since this identification, $M$. fructicola has completely displaced $M$. fructigena as a cause of brown rot, and M. fructicola and M. laxa now have the same frequency of occurrence in these peach and nectarine orchards (Villarino et al. 2013). M. fructicola has also been identified in several EPPO member countries: France (Lichou et al. 2002), the Czech Republic (Duchoslavová et al. 2007), Italy (Pellegrino et al. 2009), Germany (Grabke et al. 2011), Slovenia (Munda and Marn 2010), Serbia (Vasić et al. 2012), and Greece (Papavasileiou et al. 2015).

Monilinia infection occurs when the fungus penetrates fruit through natural openings, such as stomata, or surface injuries when weather conditions are favorable for fungal growth and development (Biggs and Northover 1988; Phillips 1984). When weather conditions are unfavorable, a latent Monilinia infection may occur (Byrde and Willetts 1977). M. fructicola and M. laxa have been isolated from peaches, nectarines, and plums with latent infections (Emery et al. 2000; Fourie and Holz 2003a, b; Gell et al. 2008; Luo et al. 2001; Northover and Cerkauskas 1994). The incidence of latent Monilinia infections in harvested fruit ranges from 0 to $30 \%$ and may even be as high as 50\% (Emery et al. 2000; Luo et al. 2001; Luo and Michailides 2001, 2003). Most stone fruit with a latent Monilinia infection do not develop visible signs of disease until the arrival of fruit at the consumer markets or the consumer's homes. Hence, fruit with a latent Monilinia infection is a silent reservoir of the pathogenic fungus. Moreover, detecting a latent Monilinia infection in stone fruit is

Corresponding author: A. De Cal; E-mail: cal@inia.es

*The $\boldsymbol{e}$-Xtra logo stands for "electronic extra" and indicates that two supplementary tables and two supplementary figures are available online.

Accepted for publication 18 January 2017.

○ 2017 The American Phytopathological Society crucial for preventing spread of the pathogenic fungus to countries and/or regions free from pathogens.

The overnight freezing-incubation technique (ONFIT) is a wellestablished method for detecting latent Monilinia infections (Luo and Michailides 2003). However, one of ONFIT's disadvantages is its duration: it takes 7 to 9 days to detect the latent infection, which is activated by causing senescence in epidermal cells by freezing the fruit at $-20^{\circ} \mathrm{C}$ for $48 \mathrm{~h}$ (Luo and Michailides 2003; Villarino et al. 2012). Once the epidermis is damaged, the fruit is first incubated for 5 to 7 days at $25^{\circ} \mathrm{C}$ and a high relative humidity (RH) and then examined for signs of brown rot.

The advent of molecular methods has enabled the rapid detection, identification, and differentiation of Monilinia spp. The first molecular method for detecting $M$. fructicola was based on amplification of the group 1 introns in the nuclear small subunit ribosomal RNA (SSU rDNA) gene by PCR (Fulton and Brown 1997). Since this method was only able to identify $M$. fructicola, new PCR-based methods, which amplify other specific regions of DNA of $M$. fructicola, M. fructigena, and M. laxa, were developed (Boehm et al. 2001; Côté et al. 2004; Förster and Adaskaveg 2000; Gell et al. 2007; Hughes et al. 2000; Ioos and Frey 2000; Ma et al. 2003). Luo et al. (2007) developed the first qPCR-based method using SYBR Green (Thermo Fisher Scietific Inc., Waltham, MA) to detect M. fructicola, and this method has since been validated for only $M$. laxa. van Brouwershaven et al. (2010) developed a qPCR-based method that uses hydrolysis probes to differentiate between M. fructicola and the three other principal causal agents of brown rot, $M$. fructigena, M. laxa, and M. polystroma (G. C. M. van Leeuwen) Kohn. Moreover Guinet et al. (2016) developed a multiplex real-time PCR assay that detects and differentiates between $M$. fructicola, $M$. fructigena, and M. laxa in just one step on both Prunus and Malus species.

No molecular methods and none of the existing qPCR-based methods have been developed for detecting a latent Monilinia infection in nectarines. Hence, the main objective of this investigation was to determine whether the qPCR-based method that was developed by van Brouwershaven et al. (2010) could be applied to rapidly, reliably, and reproducibly (i) detect a latent Monilinia infection in the blossoms and fruit of nectarine trees, and (ii) distinguish between Monilinia spp.

\section{Materials and Methods}

Fungal isolates and preparation of conidial suspensions. Twenty-eight Monilinia isolates (10 M. fructicola isolates, $8 \mathrm{M}$. fructigena isolates, and $10 \mathrm{M}$. laxa isolates) from the culture collection of Plant Protection Department of Instituto Nacional de Investigación y Tecnología Agraria y Alimentaria (INIA), Madrid, Spain, were used in the different experiments (Table 1). The Monilinia isolates of the collection were confirmed by morphological identification and PCR 
assays according to the method developed by Gell et al. (2007). The $M$. fructicola and M. laxa isolates were stored either as a conidial suspension in $20 \%$ glycerol at $-80^{\circ} \mathrm{C}$ for long-term storage or as a culture on potato dextrose agar (PDA) (Difco Laboratories, Detroit, MI) at $4{ }^{\circ} \mathrm{C}$ for short-term storage. The $M$. fructicola isolates were grown on PDA plates at 20 to $25^{\circ} \mathrm{C}$ in the dark for 7 days for conidial production. The M. laxa isolates were first grown on PDA plates in the dark at 20 to $25^{\circ} \mathrm{C}$ for 10 days and then at $4{ }^{\circ} \mathrm{C}$ for 5 days for conidial production. The $M$. fructigena isolates were maintained on PDA slants at $4^{\circ} \mathrm{C}$. For conidial production of $M$. fructigena isolates, surfacedisinfected nectarines were inoculated with 3-mm diameter mycelial plugs from 1-week-old cultures that were grown on PDA at $25^{\circ} \mathrm{C}$ in the dark. Nectarines were surface-disinfected by immersion for $5 \mathrm{~min}$ in a $1 \%$ sodium hypochlorite solution, immersion for $1 \mathrm{~min}$ in a 70\% ethanol solution, two 1-min washes in sterilized distilled water (SDW), and drying for $2 \mathrm{~h}$ in a laminar flow hood (Sauer and Burroughs 1986). The fruit were then incubated in a humidity chamber that was lined with sterilized moist filter paper at 20 to $25^{\circ} \mathrm{C}$ under fluorescent lighting (100 $\mu \mathrm{E} \mathrm{m}^{-2} \mathrm{~s}^{-1}$ with a $16 \mathrm{~h}$ photoperiod) for 7 to 10 days.

The conidial suspensions were prepared using conidia that were harvested from the PDA plates (M. fructicola and M. laxa) or from fruit (M. fructigena) by scratching the surface with a sterilized disposable scalpel after adding SDW. The harvested conidia and mycelia were filtered through glass wool in order to remove the mycelia after a $30 \mathrm{~s}$ sonication in an ultrasonic bath (J.P. Selecta S.A., Barcelona, Spain). The filtrate was adjusted to the desired conidial concentration using SDW after counting the number of conidia using a hemocytometer and a light microscope (Zeiss Axioskop 2; Carl Zeiss, Inc., Oberkochem, Germany).

Establishment of an artificial latent Monilinia infection in nectarine flowers. Due to the almost nonexistent occurrence of natural flower latent infections by Monilinia in Spanish conditions (Villarino et al. 2012), artificial latent infections were conducted to ensure Monilinia detection. Two hundred and ninety nectarine flowers without any visible signs of brown rot were collected from a 'Romea' nectarine tree in the Jerte Valley, Caceres, Spain, in 2014. After their collection, the flowers were first surface-disinfected (previously described on M. fructigena conidial production). After drying, the flowers were randomly divided in groups of 10 . Each nectarine flower in each group was inoculated placing inside the calix a $30 \mu \mathrm{l}$ conidial suspension $\left(10^{6}\right.$ conidia $\left.\mathrm{ml}^{-1}\right)$ drop of one of the $M$. fructicola, $M$. fructigena, and $M$. laxa isolates using a micropipette (approximately $780 \mathrm{pg}$ DNA). After inoculation, the flowers were incubated in sterile humidity chambers, i.e., polystyrene boxes, which were lined with moist sterilized filter paper, at $25^{\circ} \mathrm{C}$ and $100 \% \mathrm{RH}$ for $24 \mathrm{~h}$ in the dark. At the end of the incubation period, the flowers were again surface-disinfected and air-dried in a laminar flow hood, as previously described. After drying, the flowers were incubated in humidity chambers at $4{ }^{\circ} \mathrm{C}$ and $100 \%$ RH for 5 days in the dark. The control group consisted of 10 flowers, each of which was inoculated with $30 \mu$ l SDW.

Establishment of an artificial latent Monilinia infection in nectarines. Natural fruit latent infections by Monilinia have a higher frequency of occurrence than those of flowers, but they are highly variable in number (Gell et al. 2008; Villarino et al. 2012). Inducing latent infections with a high pathogen inoculum concentration ensures presence and homogeneous numbers of latent infections in nectarines, thus reducing the effects over the results of the sporadic natural latent infections. Two nectarine varieties of similar susceptibility, Alba Red and Big Top, which had been routinely used in the INIA lab over the years, were selected and used for the establishment of artificial latent infections. One hundred thirty-two nectarines of similar phenological status $(\mathrm{BBCH}=89$, at harvest; $\mathrm{BBCH}$ : general scale from Biologische Bundesantalt, Bundessortenamt and Chemische Industrie, Germany [Meier et al. 1994]) without any visible signs of brown rot were collected from orchards in the Ebro Valley,

Table 1. Identification of the 29 isolates (10 Monilinia fructicola [Mfc] isolates, 8 M. fructigena [Mfg] isolates, and $11 \mathrm{M}$. laxa [Mlx] isolates) that were used in the different experiments

\begin{tabular}{|c|c|c|c|c|c|}
\hline ID & Collection name & Monilinia species & Host & Plant material & Isolation year \\
\hline$\overline{\mathrm{Mfc} 1}$ & 2014COSALBARED36 & M. fructicola & Nectarine & Fruit & 2014 \\
\hline Mfc2 & 2014COSFANTASIA10 & M. fructicola & Nectarine & Fruit & 2014 \\
\hline Mfc3 & ALF2009COS5R7 & M. fructicola & Peach & Fruit & 2009 \\
\hline $\mathrm{Mfc} 4$ & ALB2009IL14D4R9 & M. fructicola & Peach & $\mathrm{LI}^{\mathrm{a}}$ & 2009 \\
\hline Mfc5 & ALF2009MOA4 & M. fructicola & Peach & $\mathrm{MFT}^{\mathrm{b}}$ & 2009 \\
\hline Mfc6 & SUD2009COS2R6 & M. fructicola & Nectarine & Fruit & 2009 \\
\hline Mfc7 & ALB2009PB5R14 & M. fructicola & Peach & Shoot & 2009 \\
\hline Mfc8 & ALC2013FRPC13 & M. fructicola & Peach & Fruit & 2013 \\
\hline Mfc9 & SUD2013FRPC68 & M. fructicola & Nectarine & Fruit & 2013 \\
\hline Mfc10 & SUD2012MS4.2 & M. fructicola & Nectarine & $\mathrm{MFO}^{\mathrm{c}}$ & 2012 \\
\hline Mfg1 & 71 & M. fructigena & Apple & Fruit & 2010 \\
\hline Mfg2 & 199 & M. fructigena & Apple & Fruit & 2010 \\
\hline Mfg3 & BOLAÑO1 & M. fructigena & Apple & Fruit & 2010 \\
\hline Mfg4 & BOLAÑO13 & M. fructigena & Apple & Fruit & 2010 \\
\hline Mfg5 & BOLAÑO12 & M. fructigena & Apple & Fruit & 2010 \\
\hline Mfg6 & BOLAÑO8 & M. fructigena & Apple & Fruit & 2009 \\
\hline Mfg7 & FRANZA2012.2 & M. fructigena & Apple & Fruit & 2012 \\
\hline Mfg8 & D-45 & M. fructigena & Apple & Fruit & 2009 \\
\hline Mlx1 & 2014COSFANTASIA13 & M. laxa & Nectarine & Fruit & 2014 \\
\hline Mlx2 & BRM2009ALB2.3 & M. laxa & Peach & Shoot & 2009 \\
\hline Mlx3 & FLOR2009SUD5.1 & M. laxa & Nectarine & Flower & 2009 \\
\hline Mlx4 & SUD2009IL21D8R2 & M. laxa & Nectarine & LI & 2009 \\
\hline Mlx5 & SUD2009IL14D4R1 & M. laxa & Nectarine & LI & 2009 \\
\hline Mlx6 & ALB2009ILCOS6R6(1) & M. laxa & Peach & LI & 2009 \\
\hline Mlx7 & MS2009ALF10 & M. laxa & Peach & MFO & 2009 \\
\hline Mlx8 & SUD2009IL7D5R1 & M. laxa & Nectarine & LI & 2009 \\
\hline Mlx9 & 2014COSFANTASIA9 & M. laxa & Nectarine & Fruit & 2014 \\
\hline Mlx10 & ALF2009COSLER107.1 & M. laxa & Peach & Fruit & 2009 \\
\hline Mlx11 & ALB20097DIL10R10 & M. laxa & Peach & Fruit & 2009 \\
\hline
\end{tabular}

\footnotetext{
a Tissue with latent infection.

${ }^{\mathrm{b}}$ Mummified fruit from a tree.

${ }^{\mathrm{c}}$ Mummified fruit on orchard bed.
} 
Lleida, Spain. After their collection, the nectarines were surfacedisinfected and dried in a laminar flow hood, as previously described on $M$. fructigena conidial production. After drying, the nectarines were randomly divided in groups of six, and each nectarine of each group was inoculated by a $30 \mathrm{~s}$ immersion in a conidial suspension (approximately $10^{5}$ conidia $\mathrm{ml}^{-1}$ ). Sixty-six Alba Red nectarines were inoculated with M. fructicola isolates in 2014 and 66 Big Top nectarines with $M$. laxa isolates in 2015. After inoculation, the nectarines were incubated in humidity chambers (previously described) at $25^{\circ} \mathrm{C}$ and $100 \% \mathrm{RH}$ for $24 \mathrm{~h}$ in the dark. At the end of the incubation period, the nectarines were again surface-disinfected and dried in a laminar flow hood, as previously described. After drying, the nectarines were incubated in humidity chambers (previously described) at $4{ }^{\circ} \mathrm{C}$ and $100 \% \mathrm{RH}$ for 5 days in the dark. A control group was made each year with six nectarines, each of which was immersed in SDW for $30 \mathrm{~s}$.

Detection of latent Monilinia infection by qPCR and ONFIT. Five flowers inoculated with each Monilinia isolate and five control-uninoculated flowers were stored at $-80^{\circ} \mathrm{C}$ and then lyophilized in a laboratory freeze dryer (Cryodos -50 , Azbil Telstar Technologies, SLU, Terrassa, Spain). Each lyophilized flower was placed on $2 \mathrm{ml}$ microcentrifuge tubes and homogenized for $60 \mathrm{~s}$ at a speed setting of $4.0 \mathrm{~m} / \mathrm{s}$ using a high-speed benchtop tissue homogenizer (FastPrep-24 Instrument, MP Biomedicals, Solon, OH). Genomic DNA from each flower was extracted using the DNeasy Plant Mini Kit (Qiagen GmbH, Hilden, Germany) in accordance with the manufacturer's instructions except that DNA was eluted in a final volume of $100 \mu$ l.

The epidermis and the mesocarp of three nectarines inoculated with each isolate and three control-uninoculated nectarines from each year were excised using a sterile disposal scalpel at the end of the 5 -day incubation period at $4^{\circ} \mathrm{C}$. The mesocarp was further divided into external mesocarp (from the epidermis to a depth of $1 \mathrm{~cm}$ ), and internal mesocarp (the rest of the mesocarp until the stone) so that the depth of the latent infection in each nectarine could be delimited. The different areas of each fruit were placed separately into $50 \mathrm{ml}$ centrifuge tubes, stored at $-80^{\circ} \mathrm{C}$, and lyophilized and homogenized inside each $50 \mathrm{ml}$ centrifuge tube in the conditions previously described for flowers. Genomic DNA was extracted from five randomly selected $20 \mathrm{mg}$ samples of each homogenate (nectarine epidermis, external mesocarp, or internal mesocarp) using the DNeasy Plant Mini Kit (Qiagen $\mathrm{GmbH}$ ), in accordance with the manufacturer's instructions, with the exception that the DNA was eluted in a final volume of $50 \mu l$.

DNA amount and purity in the flower and fruit specimens were determined using a Nanodrop ND-1000 spectrophotometer (NanoDrop Technologies Inc., Wilmington, Germany). The DNA concentrations

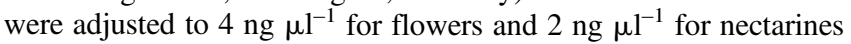
using sterile Milli-Q water for the qPCRs.

Latent Monilinia infections in the flowers and fruit were detected applying the qPCR-based method and hydrolysis probes of van Brouwershaven et al. (2010) with modifications as follows. The hydrolysis probes were labeled with different reporter dyes and quenchers and all primers and probes were obtained from Integrated DNA Technologies Inc. (Coralville, IA). Specifically, we used a FAM reporter dye and a ZEN/Iowa Black FQ quencher for $M$. fructicola probe $\left(\mathrm{P}_{-} \mathrm{fc}\right)$ instead of a FAM-TAMRA, and a HEX reporter dye with a ZEN/Iowa Black FQ quencher instead of a VIC-TAMRA quencher for $M$. fructigena and $M$. laxa probe (P2_fgn/lx/ps). Genomic DNA from the flowers (20 ng) or the three fruit areas (10 ng) was amplified in $20-\mu 1$ reaction mixture in each well of a 96-well clear optical reaction plate (Applied Biosystems, Foster City, CA) sealed with a clear adhesive. The $20-\mu$ l reaction mixture contained $1 \times$ GoTaq probe qPCR Master Mix (Promega Corporation, Madison, WI), $200 \mathrm{nM}$ of each of the primers (Mon139F and Mon 139R), and $200 \mathrm{nM}$ of each of the probes (P_fc and P2_fgn/lx/ps). Thermal cycling was done using the ABI 7500 Fast Real-Time PCR System (Applied Biosystems) under the same conditions and using the same thresholds described by van Brouwershaven et al. (2010) with slight modifications: polymerase activation at $95^{\circ} \mathrm{C}$ for $10 \mathrm{~min}$, followed by 40 amplification cycles at $95^{\circ} \mathrm{C}$ for $15 \mathrm{~s}$ and $60^{\circ} \mathrm{C}$ for $1 \mathrm{~min}$. Emission was measured at the annealing-extension step. The threshold value was set at fluorescence $(\Delta \mathrm{Rn})$ of 23,000 . A quantification cycle $\left(\mathrm{C}_{\mathrm{q}}\right)$ value below 40 was scored as a positive detection. Additionally, an allelic discrimination step was added due to cross-detection of $M$. laxa and M. fructigena when using the $\mathrm{P}_{-} \mathrm{fc}$ probe. Allelic discrimination allowed us to distinguish between the $M$. fructicola isolates, the M. fructigena isolates, the M. laxa isolates, and mixtures of the Monilinia isolates with absolute certainty. The allelic discrimination step measures fluorescence in each well of the qPCR plate before and after qPCR amplification, and places each sample in an X-Y graph according to these results. The $M$. fructicola samples are placed on a line parallel to the $\mathrm{Y}$-axis on top of the vertex formed by the negative controls while the $M$. fructigena/M. laxa samples are placed on a line parallel to the $\mathrm{X}$-axis and to the right of the vertex formed by the negative controls, and the mixtures of $M$. fructicola and $M$. fructigena/M. laxa appear between both axes with the bisectrix indicating mixtures of equal amounts.

All amplifications included the following controls: (i) a negative control (DNase- and RNase-free water) in order to check for DNA contamination, and (ii) a positive control, consisting of separate DNA samples (10 pg) from the different $M$. fructicola, $M$. fructigena, and $M$. laxa isolates in order to monitor reaction performance and efficiency of the qPCR. A proposed workflow to use this qPCR method as a diagnostic tool for latent Monilinia spp. infections can be found in Supplementary Figure S1. Supplementary Tables S1 and S2 show the qPCR plate layout for the latently infected flowers and nectarines. The results of the qPCR were considered reliable when all controls in the series gave the expected results (Kox et al. 2005, 2007).

For quantification of the DNA amount in each specimen, eight standard curves, one for each tested combination of Monilinia species (M. fructicola and M. fructigena/M. laxa) and plant material (flowers, epidermis, and mesocarp), were generated. The standard curves were generated using a 10-fold dilution series, ranging from $4 \mathrm{ng}$ to $4 \mathrm{fg}$ of genomic DNA (approximately from 154,000 to $0.15 \mathrm{M}$. laxa conidia) from each fungal species, and after spiking the samples with nectarine DNA, $20 \mathrm{ng}$ for the flowers and $10 \mathrm{ng}$ for the nectarine's epidermis and mesocarp. The genomic DNA used for the standard curves was extracted from purified cultures of isolates Mfc3 and Mlx11, and its concentration was determined using a Nanodrop ND-1000 spectrophotometer (NanoDrop Technologies Inc.). Each dilution series was done in triplicate for each standard curve. The essential parameters of the qPCR assay performance (PCR efficiency, limit of detection, and precision) were calculated according to Bustin et al. (2009). Equivalences between number of cells or conidia and DNA quantity are calculated using the haploid genome size of $0.04 \mathrm{pg}$ obtained for one $M$. laxa isolate sequenced by our group (unpublished data) and an average number of 6.6 nuclei (with a range from 4 to 10) per cell (Hall 1963; Lee and Bostock 2006).

ONFIT (Luo and Michailides 2003) was used to detect latent Monilinia infections in the remaining five flowers and three nectarines of each group. Briefly, the nectarines and flowers were first frozen at $-20^{\circ} \mathrm{C}$ for $48 \mathrm{~h}$ to induce tissue senescence. The senescent fruit and flowers were transferred to plates in humidity chambers (as previously described) and incubated at $25^{\circ} \mathrm{C}$ and $100 \% \mathrm{RH}$ for 1 week in the dark. At the end of the incubation, the fruit and the flowers were examined for visible signs of a Monilinia infection and the number of rotten plant parts was recorded for each Monilinia isolate. The frequencies of latently infected flowers and fruit that were detected by ONFIT and qPCR were compared.

Data analysis. The results of the qPCR amplifications were transformed into DNA amount for each of the three replicates of the five flowers and five samples of each of the three fruit areas individually, using the standard curves previously obtained, prior to any statistical analysis. DNA amounts were compared among each Monilinia species for the flower samples and nectarine samples. The amount of DNA of each nectarine area (epidermis, external mesocarp, and internal mesocarp) was compared for each of the Monilinia isolates. The results of the qPCR were transformed into qualitative results 
(positive detection or negative detection) in order to compare them with the results obtained with ONFIT. A positive detection was considered when a flower or at least one of the five nectarine epidermis samples of each nectarine scored a $\mathrm{C}_{\mathrm{q}}$ lower than 40. Statgraphics Centurion XVI for Windows, Version 16.1.03 (StatPoint Technologies, Inc., Herndon, VA) was used to statistically analyze the data. Because some of the qPCR results were negative for all technical replicates within a sample, heterogeneity of variance among treatments was detected. To compensate the lack of homogeneity of variance, the Kruskal-Wallis test was used to compare the medians of the amount of Monilinia DNA detected in the flowers and fruit with a latent infection. When a result of the Kruskal-Wallis test was significant $(P<0.05)$, the group medians of the samples were compared.

\section{Results}

Standard curves characteristics. Standard curves for the two hydrolysis probes ( $\mathrm{P} \_$fc $[M$. fructicola $]$ and $\mathrm{P} 2$ _fgn/lx/ps $[$ M. fructigena, M. laxa, and M. polystroma]) were done to assess the efficiency of the qPCR method in each matrix (milli-Q water, nectarine flower DNA, nectarine fruit epidermis DNA, and nectarine fruit mesocarp DNA) (Table 2). A low limit of detection (less than $27 \mathrm{fg}$ of DNA [approximately $1 M$. laxa cell]) was achieved with the different probes for all the different matrices (Table 2). With the exception of the standard curve for $M$. fructicola in flowers that have an amplification efficiency of $87 \%$, the rest of the standard curves had optimal amplification efficiencies between 90 and 100\% (Table 2). Additionally, the fit of the generated data to the regression line was high, as measured by value of the $\mathrm{R}^{2}$ coefficient that was greater than 0.99 for all curves (Table 2).

Detection of a latent Monilinia infection in nectarine flowers by qPCR. DNA from the $M$. fructicola, $M$. fructigena, and $M$. laxa isolates was not detected in the five control-uninoculated flowers. The median amounts of DNA of each $M$. fructicola, $M$. fructigena, and $M$. laxa isolate in the latently infected flowers are displayed in Figure 1 . The median amounts of DNA from $M$. fructigena and M. laxa species were similar, $0.10 \pm 0.05 \mathrm{pg}$ (median \pm standard error) and $0.13 \pm 0.06 \mathrm{pg}$, respectively, and lower than the median amount of DNA from $M$. fructicola $18.32 \pm 8.47 \mathrm{pg}$. The median amount of DNA from $M$. fructicola isolates in the latently infected flowers was bigger than $1 \mathrm{pg}$ in 8 out of 10 isolates whereas those from M. fructigena and M. laxa isolates were less than $1 \mathrm{pg}$, in 7 out of 8 and 10 out of 10 isolates, respectively. The median amount of DNA of $M$. fructicola isolates ranged between $0.25 \pm 0.11 \mathrm{pg}$ and $338.73 \pm 128.01 \mathrm{pg}$, the ones from M. fructigena isolates ranged

Table 2. Characteristics of the eight standard curves for detecting and quantifying DNA by qPCR in nectarine flowers and fruit with a latent Monilinia infection $^{\mathrm{a}}$

\begin{tabular}{|c|c|c|c|c|c|c|}
\hline Species & Sample matrix & Limit of detection (fg) & Y-intercept & Slope & $\mathrm{E}(\%)$ & $\mathbf{R}^{2}$ \\
\hline \multirow[t]{4}{*}{ M. fructicola } & Water & $8.95 \pm 2.29$ & $32.25 \pm 0.09$ & $-3.47 \pm 2.9 \times 10^{-2}$ & $94 \pm 0.87$ & 0.994 \\
\hline & Flower & $9.62 \pm 3.86$ & $30.72 \pm 0.10$ & $-3.67 \pm 0.8 \times 10^{-2}$ & $87 \pm 0.24$ & 0.996 \\
\hline & Epidermis & $4.63 \pm 0.74$ & $30.04 \pm 0.08$ & $-3.57 \pm 2.9 \times 10^{-2}$ & $91 \pm 0.98$ & 0.999 \\
\hline & Mesocarp & $4.11 \pm 1.27$ & $28.43 \pm 0.13$ & $-3.30 \pm 4.6 \times 10^{-2}$ & $100 \pm 1.96$ & 0.998 \\
\hline \multirow[t]{4}{*}{ M. laxa/M. fructigena } & Water & $26.77 \pm 3.76$ & $33.12 \pm 0.06$ & $-3.59 \pm 0.8 \times 10^{-2}$ & $90 \pm 0.28$ & 0.999 \\
\hline & Flower & $11.22 \pm 0.54$ & $31.16 \pm 0.03$ & $-3.60 \pm 1.0 \times 10^{-2}$ & $90 \pm 0.33$ & 0.996 \\
\hline & Epidermis & $3.51 \pm 0.19$ & $31.18 \pm 0.12$ & $-3.29 \pm 4.0 \times 10^{-2}$ & $100 \pm 1.67$ & 0.993 \\
\hline & Mesocarp & $4.81 \pm 0.41$ & $31.19 \pm 0.03$ & $-3.57 \pm 2.1 \times 10^{-2}$ & $91 \pm 0.75$ & 0.999 \\
\hline
\end{tabular}

${ }^{a}$ Values are displayed as means \pm standard error.
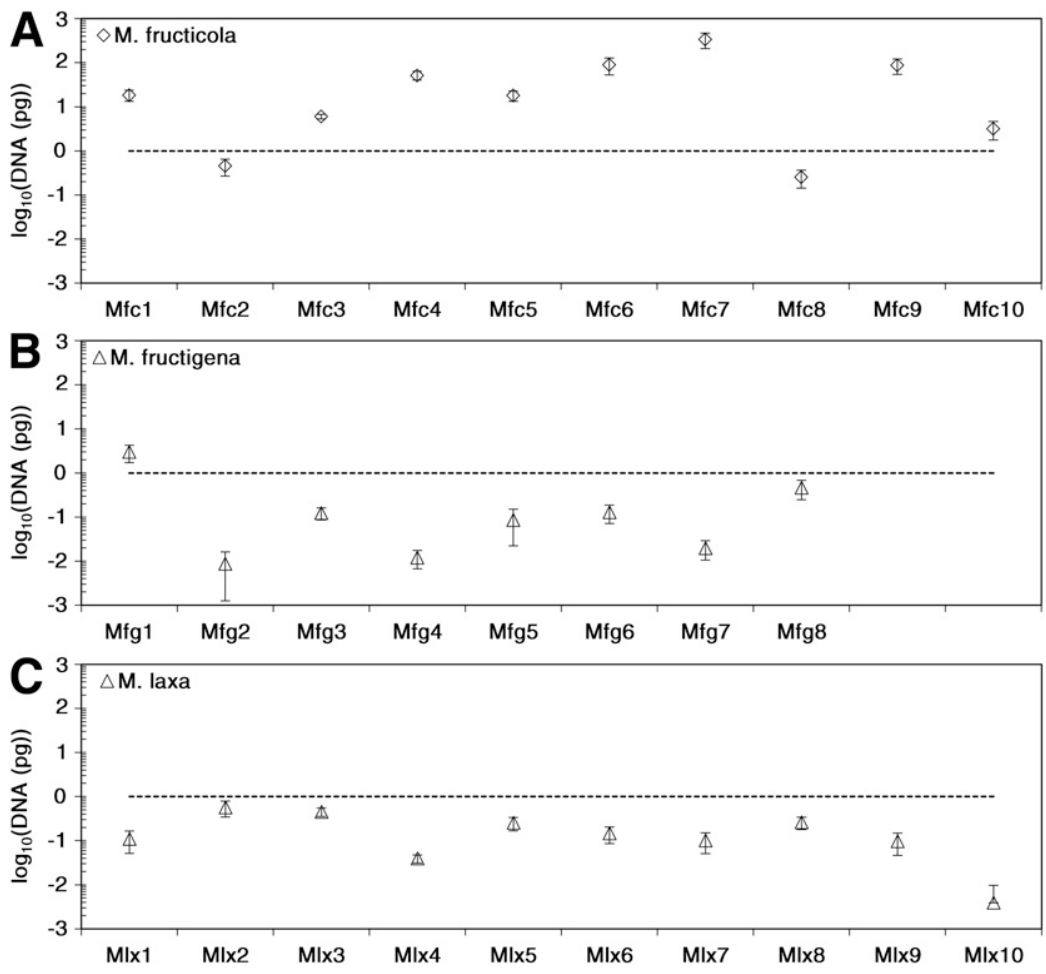

Fig. 1. Amounts of DNA from 10 Monilinia fructicola (A), 8 M. fructigena (B), and $10 \mathrm{M}$. laxa (C) isolates in latently infected flowers that were detected by qPCR. Values are displayed as median DNA amount \pm standard error of five inoculated flowers and three pseudo-replicates per repetition. Dotted lines at $1 \mathrm{pg}$ DNA divide the graphs to highlight the differences, and facilitate the comparison between graphs. 
between $0.01 \pm 0.01 \mathrm{pg}$ and $3.00 \pm 1.28 \mathrm{pg}$, and those from $M$. laxa isolates ranged between $0.004 \pm 0.006 \mathrm{pg}$ and $0.57 \pm 0.22 \mathrm{pg}$ (Fig. 1).

Detection of latent Monilinia infection in nectarines by qPCR. Latent brown rot infections in the epidermis and the mesocarp of inoculated nectarines that were caused by M. fructicola and M. laxa isolates were successfully detected by qPCR. DNA from the $M$. fructicola and M. laxa isolates was not detected in the epidermis and the mesocarp of two out of the three control-uninoculated nectarines from 2014 and the three control-uninoculated nectarines from 2015. The third control-uninoculated nectarine from 2014 had a natural latent Monilinia infection because the qPCR detected $M$. fructicola DNA in its epidermis $(2.27 \pm 0.23 \mathrm{pg}$ DNA). The median amounts of DNA from each $M$. fructicola and $M$. laxa isolate in the epidermis, the external mesocarp, and the internal mesocarp of latently infected nectarines where similar inside each specie and those corresponding to isolate $\mathrm{Mfc} 3$ and Mlx4 are shown on Figure 2; additionally, the values for all of the isolates are shown in Supplementary Figure S2. For the M. fructicola and M. laxa isolates, the amounts of their DNA detected in the epidermis were greater than those in the external and internal mesocarp of latently infected nectarines, except for Mlx2 and Mlx8. The amounts of DNA from the $M$. fructicola in the epidermis of latently infected nectarines ranged between $0.25 \pm 0.03 \mathrm{pg}$ and $6.33 \pm 0.60 \mathrm{pg}$, and were similar to those from the M. laxa isolates that ranged between $0.01 \pm 0.004 \mathrm{pg}$ and $9.10 \pm 3.26 \mathrm{pg}$ (Fig. 2). In contrast, the amount of DNA from the $M$. fructicola isolates in the mesocarp of latently infected nectarines ranged between $0.0002 \pm 0.0003 \mathrm{pg}$ and $0.004 \pm 0.001 \mathrm{pg}$, and was significantly lower than that of the $M$. laxa isolates that ranged between $0.005 \pm 0.01 \mathrm{pg}$ and $2.10 \pm 0.72 \mathrm{pg}$ (Fig. 2). There were no significant differences between external and internal mesocarp median DNA amounts, except in the latent infections caused by Mfc9, Mlx3, Mlx4, Mlx5, and Mlx6 isolates, external mesocarp Monilinia DNA amount was greater than the internal mesocarp Monilinia DNA amount.

Comparison between ONFIT and qPCR for detecting a latent Monilinia infection. The qPCR-based method for the detection of Monilinia latent infections was compared with ONFIT, the commonly used latent infection detection method, to assess its efficiency and sensitivity. Table 3 summarizes the percentages of the latent infections detected in the flowers and nectarines by ONFIT and qPCR.

Five out of 28 Monilinia isolates latently infecting flowers, four $M$. fructicola, and one M. laxa isolates, were detected by ONFIT, whereas qPCR detected all Monilinia isolates latently infecting flowers, except for isolate Mlx10 (Table 3). Eighteen of the isolates were detected in all infected flowers by qPCR (100\%), while only

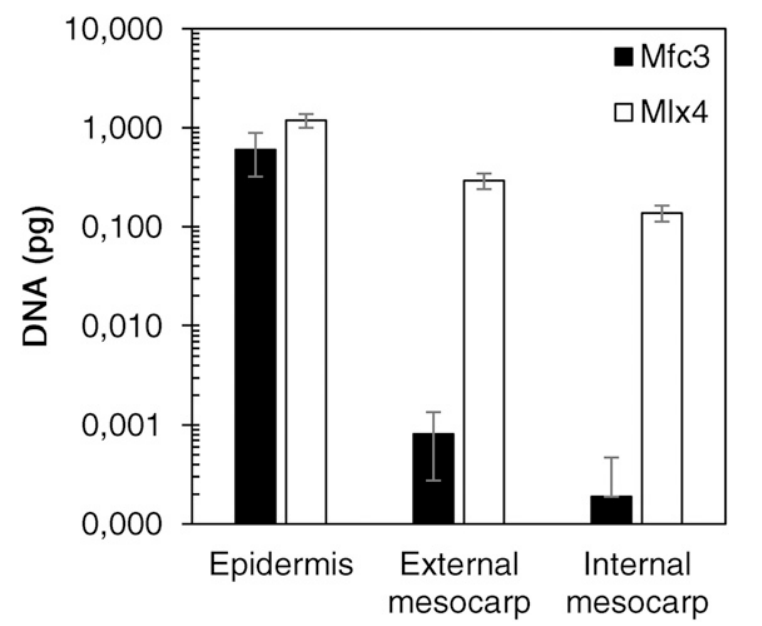

Fig. 2. Amounts of DNA from Monilinia fructicola isolate Mfc3 ( - ) and M. laxa isolate MIX4 ( $\square$ ) from the epidermis, external mesocarp, and internal mesocarp of three latently infected nectarines that were detected by qPCR. Values are displayed as median DNA amount \pm standard error of three different inoculated fruit, five DNA extractions, and three pseudo-replicates. isolate Mfc8 was detected in all latently infected flowers by ONFIT (Table 3).

The ONFIT method only detected nine $M$. fructicola and no $M$. laxa isolates latently infecting nectarines whereas the qPCRmethod detected all $10 \mathrm{M}$. fructicola and $10 \mathrm{M}$. laxa isolates latently infecting nectarines (Table 3). Furthermore, qPCR detected the latent infections in all infected nectarines from all M. fructicola isolates and nine M. laxa isolates, while ONFIT only detected $100 \%$ latent infections in five of the $M$. fructicola isolates.

Overall, qPCR detected 67\% more latent infections than ONFIT in both flowers and nectarines as estimated from the above detection frequencies in both methods.

\section{Discussion}

In this study, a qPCR-based method was used to detect latent brown rot infections in nectarine flowers and fruits caused by $M$. fructicola, $M$. fructigena, and M. laxa. It takes between 24 and $48 \mathrm{~h}$ to detect the fungal pathogen in latently infected flowers and fruit using $\mathrm{qPCR}$, while the ONFIT method required a much longer time to detect latent brown rot infections: 7 to 9 days of sample preparation an incubation plus additional time to identify the specific Monilinia spp. by PCR or another molecular method. The rapid detection of latent fungal infections is very important for predicting an outbreak of brown rot in fruit after their harvest and/or after their storage (Thomidis and Michailides 2010). We have previously reported that the average incidence of latent infection during the crop season in Spanish peach orchards explains 55\% of the total variation in the incidence of postharvest brown rot (Gell et al. 2008). Therefore, the early, rapid, and accurate detection of latent brown rot infections in the field could be useful for developing disease prediction models and improving the timing of application and efficacy of preharvest

Table 3. Detection percentages of Monilinia isolates artificial latent infections of flowers and nectarines by ONFIT and qPCR

\begin{tabular}{|c|c|c|c|c|}
\hline \multirow[b]{2}{*}{ ID } & \multicolumn{2}{|c|}{ Flowers $^{\mathbf{a}}$} & \multicolumn{2}{|c|}{ Nectarines $^{\mathbf{b}}$} \\
\hline & ONFIT (\%) & $\operatorname{qPCR}(\%)^{\mathbf{c}}$ & ONFIT (\%) & qPCR $(\%)^{\mathbf{c}}$ \\
\hline Mfc1 & 0 & 100 & 33 & 100 \\
\hline Mfc2 & 0 & 100 & 33 & 100 \\
\hline Mfc3 & 0 & 100 & 0 & 100 \\
\hline Mfc4 & 20 & 100 & 100 & 100 \\
\hline Mfc5 & 40 & 100 & 100 & 100 \\
\hline Mfc6 & 40 & 100 & 67 & 100 \\
\hline Mfc7 & 0 & 100 & 100 & 100 \\
\hline Mfc8 & 100 & 80 & 100 & 100 \\
\hline Mfc9 & 0 & 100 & 33 & 100 \\
\hline Mfc10 & 0 & 100 & 100 & 100 \\
\hline Mfg1 & 0 & 100 & - & - \\
\hline Mfg2 & 0 & 40 & - & - \\
\hline Mfg3 & 0 & 100 & - & - \\
\hline Mfg4 & 0 & 80 & - & - \\
\hline Mfg5 & 0 & 40 & - & - \\
\hline Mfg6 & 0 & 100 & - & - \\
\hline Mfg7 & 0 & 80 & - & - \\
\hline Mfg8 & 0 & 60 & - & - \\
\hline Mlx 1 & 0 & 80 & 0 & 100 \\
\hline Mlx2 & 20 & 100 & 0 & 100 \\
\hline Mlx3 & 0 & 100 & 0 & 100 \\
\hline Mlx4 & 0 & 100 & 0 & 100 \\
\hline Mlx5 & 0 & 100 & 0 & 100 \\
\hline Mlx6 & 0 & 100 & 0 & 100 \\
\hline Mlx7 & 0 & 80 & 0 & 100 \\
\hline Mlx8 & 0 & 100 & 0 & 33 \\
\hline Mlx9 & 0 & 80 & 0 & 100 \\
\hline Mlx 10 & 0 & 0 & 0 & 100 \\
\hline
\end{tabular}

a Percentages are based on five artificially latent infected nectarine flowers.

b Percentages are based on three artificially latent infected nectarines.

${ }^{\mathrm{c}}$ Positive detection was considered when Monilinia DNA was amplified in one of the flowers or at least one of the five DNA extractions of each nectarine epidermis. 
control methods. Furthermore, the early, rapid, and accurate detection of latent brown rot infections might help producers and wholesalers choose fruit intended for long-term storage or transported to distant markets, as suggested by Sanzani et al. (2012) for the control of Botrytis cinerea in table grapes.

We found that the qPCR-based method is more reliable and consistent than ONFIT because the number of positive detections and the number of replicates scoring positive detections was higher, especially when it was used for detecting latent brown rot infections that were caused by $M$. fructigena and M. laxa. The growth rate of $M$. fructicola over the nectarine surface is faster than that of M. laxa (Villarino et al. 2016), and this difference in growth rate could cause $M$. fructigena and $M$. laxa isolate presence to be lower than their disease thresholds after the second surface-disinfection and hence not being detected by ONFIT. However, many authors have reported that qPCR detects all DNA, including DNA from nonviable isolates, and this undiscriminating ability of qPCR could give false positives and an overestimation of the number of positive detections (Fittipaldi et al. 2012; Wang and Levin 2006). We detected greater amounts of $M$. fructicola than $M$. laxa DNA and $M$. fructigena DNA in latently infected flowers using qPCR. We found that latent $M$. laxa infections had greater DNA amounts in the mesocarp of latently infected nectarines than $M$. fructicola, which could indicate $M$. laxa has a higher colonization of the mesocarp during latent infections than M. fructicola. This deeper colonization of the nectarines by $M$. laxa could increase the time needed for brown rot symptoms to appear in $M$. laxa latently infected nectarines, explaining the low ONFIT detection scores for M. laxa.

Although conventional PCR and qPCR-based methods have already been developed for identifying and discriminating Monilinia species, these methods rely on sampling plant material with visible disease (Côté et al. 2004; Gell et al. 2007; Guinet et al. 2016; Hughes et al. 2000; Ioos and Frey 2000; van Brouwershaven et al. 2010). We found that the qPCR-based method can detect the pathogen in artificial and natural latent brown rot infections. Many authors have reported that qPCR has a higher sensitivity and test specificity than conventional PCR for detecting and quantifying the DNA of soilborne fungi, oomycetes, bacteria, nematodes, viruses, and phytoplasmas (Baric et al. 2006; Ippolito et al. 2004; Lievens et al. 2006; Schena et al. 2004, 2013). PCR-based methods are also considered the most effective method for detecting infectious microorganisms with a low titer and an uneven distribution in plants, such as apple proliferation phytoplasma (Baric et al. 2006).

This study proves that the qPCR method developed by van Brouwershaven et al. (2010) could be modified and used to detect latent Monilinia infections. Both studies presented good amplification efficiencies and $\mathrm{R}^{2}$ values; however, the limits of detection shown in the present study (lower than $27 \mathrm{fg}$ ) are smaller than those presented in the study by van Brouwershaven et al. (2010) (600 fg). Moreover, cross detection of M. fructigena and M. laxa was found when using the $\mathrm{P}_{-}$fc probe on this study and an additional allelic discrimination step had to be added to distinguish between $M$. fructicola and M. fructigena/M. laxa while van Brouwershaven et al. (2010) did not detect any cross identification. These differences both in limit of detection and cross-identification can be explained by either the different probe and primer manufacturers or the different $\mathrm{qPCR}$ platform used.

The advantages of the qPCR-based method for detecting a latent Monilinia infection in nectarines are its high sensitivity, its ease and rapidity of execution, the low number of handling steps, and reduced personnel costs. The disadvantages of the qPCR-based method for detecting a latent Monilinia infection in nectarines are the high cost of consumables and reagents, which are much greater than those of ONFIT, and the occurrence of false positives due to detection of nonviable fungal DNA. The number of false positive detections could be reduced by using RNA instead of DNA for qPCR amplification or fluorescent photo affinity labels (photo reactive DNA binding dyes), such as ethidium monoazide or propidium monoazide (Fittipaldi et al. 2012).
To conclude, we propose that the qPCR-based method could be used for detecting latent Monilinia infections in stone fruits with latent infections, although specific experiments on peaches, plums, and cherries should be done (Emery et al. 2000; Luo and Michailides 2001; Northover and Cerkauskas 1994). We also conclude that the qPCR-based method will also be very useful for detecting latent Monilinia spp. infections in those countries where Monilinia spp. are classified as quarantine fungal pathogens.

\section{Acknowledgments}

This study was supported by grants 266505 FP7-ERANET EUPHRESCO II DIMO (ERA37-DIMO-INIA) and AGL2014-55287-CO2-01 from the Ministry of Science and Innovation (Spain). C. Garcia-Benitez received a scholarship from the Ministry of Science and Innovation (Spain). We thank R. Castillo, M. T. Morales Clemente, and F. Martínez Pérez for their technical collaboration. The authors would also like to thank Dr. Arieh Bomzon, ConsulWrite (www.consulwrite.com) for his editorial assistance in preparing this manuscript.

\section{Literature Cited}

Baric, S., Kerschbamer, C., and Dalla Via, J. 2006. TaqMan real-time PCR versus four conventional PCR assays for detection of apple proliferation phytoplasma. Plant Mol. Biol. Report. 24:169-184.

Biggs, A. R., and Northover, J. 1988. Early and late-season susceptibility of peach fruits to Monilinia fructicola. Plant Dis. 72:1070-1074.

Boehm, E. W. A., Ma, Z., and Michailides, T. J. 2001. Species-specific detection of Monilinia fructicola from California stone fruits and flowers. Phytopathology 91:428-439.

Bustin, S. A., Benes, V., Garson, J. A., Hellemans, J., Huggett, J., Kubista, M., Mueller, R., Nolan, T., Pfaffl, M. W., Shipley, G. L., Vandesompele, J., and Wittwer, C. T. 2009. The MIQE guidelines: minimum information for publication of quantitative real-time PCR experiments. Clin. Chem. 55: 611-622.

Byrde, R. J., and Willetts, H. J. 1977. The brown rot fungi of fruit: their biology and control. Pergamon Press, Oxford, U.K

Côté, M. J., Tardif, M. C., and Meldrum, A. J. 2004. Identification of Monilinia fructigena, M. fructicola, M. laxa, and Monilia polystroma on inoculated and naturally infected fruit using multiplex PCR. Plant Dis. 88:1219-1225.

De Cal, A., Gell, I., Usall, J., Viñas, I., and Melgarejo, P. 2009. First report of brown rot caused by Monilinia fructicola in peach orchards in Ebro valley, Spain. Plant Dis. 93:763.

Duchoslavová, J., Širučková, I., Zapletalová, E., Navrátil, M., and Šafářová, D. 2007. First report of brown rot caused by Monilinia fructicola on various stone and pome fruits in the Czech Republic. Plant Dis. 91:907.

Emery, K. M., Michailides, T. J., and Scherm, H. 2000. Incidence of latent infection of immature peach fruit by Monilinia fructicola and relationship to brown rot in Georgia. Plant Dis. 84:853-857.

EPPO. 2009. PM 7/18 (2) Monilinia fructicola. EPPO Bull. 39:337-343.

Fittipaldi, M., Nocker, A., and Codony, F. 2012. Progress in understanding preferential detection of live cells using viability dyes in combination with DNA amplification. J. Microbiol. Methods 91:276-289.

Förster, H., and Adaskaveg, J. E. 2000. Early brown rot infections in sweet cherry fruit are detected by Monilinia-specific DNA primers. Phytopathology 90: 171-178.

Fourie, P. H., and Holz, G. 2003a. Germination of dry, airborne conidia of Monilinia laxa and disease expression on nectarine fruit. Australas. Plant Pathol. 32:9-18.

Fourie, P. H., and Holz, G. 2003b. Germination of dry, airborne conidia of Monilinia laxa and disease expression on plum fruit. Australas. Plant Pathol. 32:19-25

Fulton, C. E., and Brown, A. E. 1997. Use of SSU rDNA group-I intron to distinguish Monilinia fructicola from $M$. laxa and M. fructigena. FEMS Microbiol. Lett. 157:307-312.

Gell, I., Cubero, J., and Melgarejo, P. 2007. Two different PCR approaches for universal diagnosis of brown rot and identification of Monilinia spp. in stone fruit trees. J. Appl. Microbiol. 103:2629-2637.

Gell, I., De Cal, A., Torres, R., Usall, J., and Melgarejo, P. 2008. Relationship between the incidence of latent infections caused by Monilinia spp. and the incidence of brown rot of peach fruit: factors affecting latent infection. Eur. J. Plant Pathol. 121:487-498.

Grabke, A., Hu, M. J., Luo, C. X., Bryson, P. K., and Schnabel, G. 2011. First report of brown rot of apple caused by Monilinia fructicola in Germany. Plant Dis. 95:772.

Guinet, C., Fourrier-Jeandel, C., Cerf-Wendling, I., and Ioos, R. 2016. One-step detection of Monilinia fructicola, $M$. fructigena, and M. laxa on Prunus and Malus by a multiplex real-time PCR assay. Plant Dis. 100:2465-2474.

Hall, R. 1963. Cytology of the asexual stages of the Australian brown rot fungus Monilinia fructicola (Wint.) Honey. Cytologia (Tokyo) 28:181-193.

Hughes, K. J. D., Fulton, C. E., McReynold, D., and Lane, C. R. 2000 Development of new PCR primers for identification of Monilinia species. EPPO Bull. 30:507-511. 
Ioos, R., and Frey, P. 2000. Genomic variation within Monilinia laxa, $M$. fructigena and $M$. fructicola, and application to species identification by PCR. Eur. J. Plant Pathol. 106:373-378.

Ippolito, A., Schena, L., Nigro, F., Soleti Ligorio, V., and Yaseen, T. 2004. Realtime detection of Phytophthora nicotianae and P. citrophthora in citrus roots and soil. Eur. J. Plant Pathol. 110:833-843.

Kox, L. F. F., Boxman, I. L. A., Jansen, C. C. C., and Roenhorst, J. W. 2005. Reliability of nucleic acid amplification techniques: modified target RNA as exogenous internal standard for a real-time RT-PCR for Potato spindle tuber pospiviroid. EPPO Bull. 35:117-124.

Kox, L. F. F., van Brouwershaven, I. R., van de Vossenberg, B. T. L. H., van den Beld, H. E., Bonants, P. J. M., and de Gruyter, J. 2007. Diagnostic values and utility of immunological, morphological, and molecular methods for in planta detection of Phytophthora ramorum. Phytopathology 97:1119-1129.

Lee, M. H., and Bostock, R. M. 2006. Agrobacterium T-DNA-mediated integration and gene replacement in the brown rot pathogen Monilinia fructicola. Curr. Genet. 49:309-322.

Lichou, J., Mandrin, J. F., Bréniaux, D., Mercier, V., Giauque, P., Desbrus, D., Blanc, P., and Belluau, E. 2002. Une nouvelle moniliose. Monilia fructicola s'attaque aux arbres fruitiers à noyaux. Phytoma Def. Vegetaux 547:22-25.

Lievens, B., Brouwer, M., Vanachter, A. C. R. C., Cammue, B. P. A., and Thomma, B. P. H. J. 2006. Real-time PCR for detection and quantification of fungal and oomycete tomato pathogens in plant and soil samples. Plant Sci. 171:155-165.

Luo, Y., Ma, Z., and Michailides, T. J. 2001. Analysis of factors affecting latent infection and sporulation of Monilinia fructicola on prune fruit. Plant Dis. 85:999-1003.

Luo, Y., Ma, Z., Reyes, H. C., Morgan, D., and Michailides, T. J. 2007. Quantification of airborne spores of Monilinia fructicola in stone fruit orchards of California using real-time PCR. Eur. J. Plant Pathol. 118: 145-154.

Luo, Y., and Michailides, T. J. 2001. Factors affecting latent infection of prune fruit by Monilinia fructicola. Phytopathology 91:864-872.

Luo, Y., and Michailides, T. J. 2003. Threshold conditions that lead latent infection to prune fruit rot caused by Monilinia fructicola. Phytopathology 93:102-111.

Ma, Z., Luo, Y., and Michailides, T. J. 2003. Nested PCR assays for detection of Monilinia fructicola in stone fruit orchards and Botryosphaeria dothidea from pistachios in California. J. Phytopathol. 151:312-322.

Meier, U., Graf, H., Hess, M., Kennel, W., Klose, R., Mappes, D., Seipp, D., Stauss, R., Streif, J., and van den Boom, T. 1994. Phänologische Entwicklungsstadien des Kernobstes (Malus domestica Borkh. und Pyrus communis L.), des Steinobstes (Prunus-Arten), der Johannisbeere (Ribes-Arten) und der Erdbeere (Fragaria×ananassa Duch.). Nachrichtenbl. Deut Pflanzenschutzd 46:141-153.
Munda, A., and Marn, M. V. 2010. First report of brown rot caused by Monilinia fructicola affecting peach orchards in Slovenia. Plant Dis. 94:1166.

Northover, J., and Cerkauskas, R. F. 1994. Detection and significance of symptomless latent infections of Monilinia fructicola in plums. Can. J. Plant Pathol. 16:30-36.

Papavasileiou, A., Testempasis, S., Michailides, T. J., and Karaoglanidis, G. S. 2015. Frequency of brown rot fungi on blossoms and fruit in stone fruit orchards in Greece. Plant Pathol. 64:416-424.

Pellegrino, C., Gullino, M. L., Garibaldi, A., and Spadaro, D. 2009. First report of brown rot of stone fruit caused by Monilinia fructicola in Italy. Plant Dis. 93: 668.

Phillips, D. J. 1984. Effect of temperature on Monilinia fructicola conidia produced on fresh stone fruits. Plant Dis. 68:610-612.

Sanzani, S. M., Schena, L., De Cicco, V., and Ippolito, A. 2012. Early detection of Botrytis cinerea latent infections as a tool to improve postharvest quality of table grapes. Postharvest Biol. Technol. 68:64-71.

Sauer, D. B., and Burroughs, R. 1986. Disinfection of seed surfaces with sodiumhypochlorite. Phytopathology 76:745-749.

Schena, L., Li Destri Nicosia, M. G., Sanzani, S. M., Faedda, R., Ippolito, A., and Cacciola, S. O. 2013. Development of quantitative PCR detection methods for phytopathogenic fungi and oomycetes. J. Plant Pathol. 95:7-24.

Schena, L., Nigro, F., Ippolito, A., and Gallitelli, D. 2004. Real-time quantitative PCR: a new technology to detect and study phytopathogenic and antagonistic fungi. Eur. J. Plant Pathol. 110:893-908.

Thomidis, T., and Michailides, T. J. 2010. Development and implementation of cost-effective strategies to manage brown rot of peach trees in Imathia, Greece. Eur. J. Plant Pathol. 126:575-582.

van Brouwershaven, I. R., Bruil, M. L., van Leeuwen, G. C. M., and Kox, L. F. F. 2010. A real-time (TaqMan) PCR assay to differentiate Monilinia fructicola from other brown rot fungi of fruit crops. Plant Pathol. 59:548-555.

Vasić, M., Duduk, N., Ivanović, M. M., Obradović, A., and Ivanović, M. S. 2012. First report of brown rot caused by Monilinia fructicola on stored apple in Serbia. Plant Dis. 96:456.

Villarino, M., Egüen, B., Lamarca, N., Segarra, J., Usall, J., Melgarejo, P., and De Cal, A. 2013. Occurrence of Monilinia laxa and M. fructigena after introduction of M. fructicola in peach orchards in Spain. Eur. J. Plant Pathol. 137:835-845.

Villarino, M., Melgarejo, P., and De Cal, A. 2016. Growth and aggressiveness factors affecting Monilinia spp. survival peaches. Int. J. Food Microbiol. 227: $6-12$.

Villarino, M., Melgarejo, P., Usall, J., Segarra, J., Lamarca, N., and De Cal, A. 2012. Secondary inoculum dynamics of Monilinia spp. and relationship to the incidence of postharvest brown rot in peaches and the weather conditions during the growing season. Eur. J. Plant Pathol. 133:585-598.

Wang, S. S., and Levin, R. E. 2006. Discrimination of viable Vibrio vulnificus cells from dead cells in real-time PCR. J. Microbiol. Methods 64:1-8. 